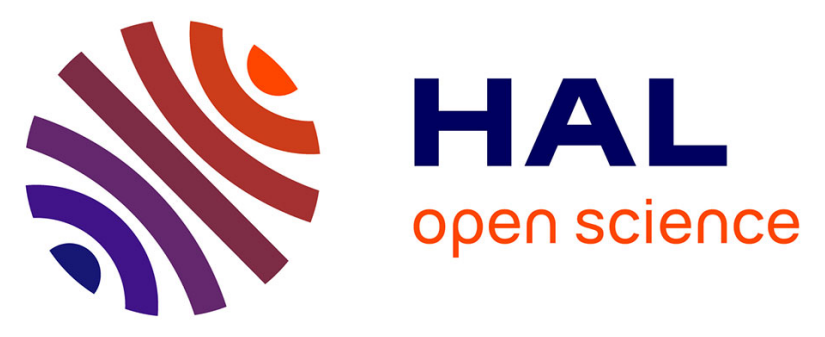

\title{
Climatic effects on soil trophic networks and the resulting humus profiles in holm oak (Quercus rotundifolia) forests in the High Atlas of Morocco as revealed by correspondence analysis
}

Nassima Sadaka, Jean-François Ponge

\section{To cite this version:}

Nassima Sadaka, Jean-François Ponge. Climatic effects on soil trophic networks and the resulting humus profiles in holm oak (Quercus rotundifolia) forests in the High Atlas of Morocco as revealed by correspondence analysis. European Journal of Soil Science, 2003, 54 (4), pp.767-777. 10.1046/j.13652389.2003.00566.x . hal-00497772

\author{
HAL Id: hal-00497772 \\ https://hal.science/hal-00497772
}

Submitted on 5 Jul 2010

HAL is a multi-disciplinary open access archive for the deposit and dissemination of scientific research documents, whether they are published or not. The documents may come from teaching and research institutions in France or abroad, or from public or private research centers.
L'archive ouverte pluridisciplinaire HAL, est destinée au dépôt et à la diffusion de documents scientifiques de niveau recherche, publiés ou non, émanant des établissements d'enseignement et de recherche français ou étrangers, des laboratoires publics ou privés. 


\title{
Climatic effects on soil trophic networks and the resulting humus
} profiles in holm oak (Quercus rotundifolia) forests in the High Atlas

\section{of Morocco as revealed by correspondence analysis}

\author{
N. SADAKA ${ }^{1} \&$ J.F. PONGE
}

Muséum National d'Histoire Naturelle, Laboratoire d'Écologie Générale, 4 avenue du PetitChâteau, 91800 Brunoy, France

Short title: Humus forms in holm oak forests

\section{Summary}

Multivariate methods have been widely used for revealing the structures of communities, and in this paper we explore one particular method, namely correspondence analysis (also called reciprocal averaging) for studying humus profiles by the 'method of small volumes'. The present study was done on humus profiles under holm oak (Quercus rotundifolia), an evergreen Mediterranean species, in the High Atlas of Morocco. Three sites (1500 m, 1700 m, 1900 m altitude) and two years (1999 and 2002) were compared. The humus form is Dysmull (mull with thick litter horizons), with variations in the thickness of OL (entire leaves), OF (fragmented leaves with faecal pellets) and A (hemorganic) horizons according to altitude and year. The dead leaves are rapidly incorporated into holorganic (earthworm, insect) and hemorganic (enchytraeid) animal faeces, which form the bulk of OF and A horizons. The S horizon (weathering parent rock) shows the greatest development of the root system. As

\footnotetext{
${ }^{1}$ Present address: Université Cadi Ayyad, Faculté des Sciences Semlalia, Département de Biologie, Laboratoire d'Écologie Terrestre, Boulevard Prince My Abdellah, 40000 Marrakech, Morocco

Correspondence: J.F. Ponge. E-mail: jean-francois.ponge@wanadoo.fr
} 
altitude increases more fresh litter (OL) or more humified organic matter (OF, A) is accumulated. Variation from year to year is depicted by opposite differences in the amount of entire oak leaves and of dead roots. Humus components (classes) are used as active (main) variables, after standardization of their mean and variance. The addition of numerous passive (additional variables), standardized in the same way as active variables, enabled us to understand the influence of biological and climatic effects on the composition of humus profiles and soil trophic networks.

\section{Introduction}

The analysis of topsoil horizons based on the identification of humus components created by biological activity (animal faeces, plant organs at different decomposition stages), called 'method of small volumes' (Ponge, 1984; Bernier \& Ponge, 1994), may help to throw light on foodwebs in the soil, and their changes under natural or human influences. Traits of the past and trends for the future may also be derived from the observation of successive horizons (Bernier \& Ponge, 1994; Gillet \& Ponge, 2002).

When several humus profiles, taken from different sites, have to be compared, our interest could be to find a synthetic description of the whole set of samples, beside the information given by individual profiles. The purpose of the present study was to apply a multivariate method to the description of a set of humus profiles, each taken in a given environmental condition, when the absence of replication prevents the use of statistical tests. As an example, six humus profiles, each composed of a varying number of layers, have been compared in mountain holm oak forests (Quercus rotundifolia) from the Moroccan Atlas, where large differences are expected to occur according to altitude and time.

Given the efficiency of correspondence analysis (Greenacre, 1994) for disentangling complex relationships between living organisms and ecological factors in the absence of 
replication (Ponge, 1993; Loranger et al., 2001), we postulated that this multivariate method could be applied to the analysis of the complex variation in humus profiles which result from changes in litter amount and climate effects on soil animal and microbial communities.

Compared with the leaves of deciduous oak, evergreen oak leaves decay slowly because they are tough and contain much lignin and tannin. Despite these features, which indicate recalcitrance of the litter towards microbial decomposition, Rapp (1971) observed a rapid incorporation of dead leaves in humus, pointing to the importance of soil fauna as active comminuters and humifiers of the litter. Previous studies have shown that the white rot Marasmius quercophilus Pouzar was chiefly responsible for the strong loss of weight and the increase in nitrogen content observed when leaves of $Q$. rotundifolia become bleached (Sadaka-Laulan \& Ponge, 2000a), and that this fungus, and the leaves it colonized, were highly attractive to saprophagous fauna (Sadaka-Laulan \& Ponge, 2000b). Thus we may hypothesize that, although at first sight resistent to microbial degradation, holm oak litter decomposes through an active trophic network involving mutual relations between microbes and animals (Lavelle, 1987, 2000).

\section{Material and methods}

Holm oak with sweet acorns (Quercus rotundifolia Lam.) is an evergreen Mediterranean tree common in western Mediterranean countries (Morocco, Algeria, Tunisia, Central Spain), mostly in mountains where it tolerates a dry and cold climate (Achhal et al., 1980; Barbero \& Loisel, 1980). It is characterized by persistent, spiny, sclerophyllous foliage. Litter falls throughout the year, mainly from April to June. The thickness of litter is determined by seasonal litter fall, decomposition rate, and biennial cycles of large and small amounts of litter input (Rapp, 1971; Poli et al., 1974; Sadaka-Laulan \& Ponge, 2000a).

\section{Study sites}


We made our study in 1999 and 2002 in a holm oak forest at Toufliht (on the northern slopes of the High Atlas, Morocco). The climate is sub-humid to semi-arid Mediterranean, with most precipitation from October to February and a long warm dry period from May to September (mean annual rainfall $840 \mathrm{~mm}$; maximum summer temperature ca $30.5^{\circ} \mathrm{C}$ and minimum winter temperature $\mathrm{ca} 1^{\circ} \mathrm{C}$ ). The parent rock is Triassic molasse comprising alternating beds of red clay, sandstone and conglomerate (Beauchamp \& Biron, 1982).

Three sites (SI, SII and SIII), where Q. rotundifolia is the dominant tree species (3-7 m height, 85-95 \%cover), were chosen according to an altitudinal gradient from 1500 to $1900 \mathrm{~m}$ above sea level. At the site SI (1500 m, N-NE aspect), the shrub layer consisted of Juniperus oxycedrus L. and Cistus monspeliensis L. At SII (1700 m, N-NE aspect), the shrub layer consisted of J. oxycedrus, C. monspeliensis, Cistus salvifolius L. and Nerium oleander L. At SIII (1900 m, E-SE aspect), the evergreen oak was associated with J. oxycedrus, Pinus halepensis L., Cistus laurifolius L. and Chamaerops humilis L.

Despite variations in litter thickness, the humus form is always of the Dysmull type (Brêthes et al., 1995), with a thick (> $1 \mathrm{~cm}$ ) OF horizon and an A horizon with a microcrumb structure. The $\mathrm{pH}$ (in water) of the A horizon was 5.5-5.8. The A horizon overlaid a S horizon, made of weathered parent rock.

\section{Sampling procedure}

In 1999 and 2002, at each site, a humus block $25 \mathrm{~cm}^{2}$ area and 8.5 to $11.5 \mathrm{~cm}$ depth was excavated by the method devised by Ponge (1984). It was cut with a sharp knife, with as little disturbance as possible, and the litter and soil surrounding it were gently excavated. Layers, about 0.5 to $2.5 \mathrm{~cm}$ thickness, were separated directly in the field from the top to the bottom of the profile on the basis of morphological differences visible to the nake eye, and 
immediately preserved in $95 \%$ ethyl alcohol (Table 1). Their thickness was noted beforehand. Biogenic structures present in the different layers were fixed and consolidated through precipitation of colloids by ethyl alcohol. Samples were classified into OL (entire leaves), OF (fragmented leaves with faecal pellets), A (hemorganic horizon) and S (mineral horizon), taking as a basis the classification of forest humus horizons by Brêthes et al. (1995). When several layers were sampled in the same horizon (on the basis of visible differences) they were numbered according to their order from the top to the bottom of a given horizon, for example OL1, OL2, OF1, OF2... Thus A2 (Table 1) was not an $\mathrm{A}_{2}$ horizon (eluvial horizon in past European classifications) but it was just the second layer sampled in the A horizon.

The fixed material was examined under a dissecting microscope (at $x 40$ magnification), with a cross reticle in the eye piece. Each layer was transferred to a Petri dish filled with ethyl alcohol, then a 200-point grid was positioned over the studied material, and the points that covered each class of humus component were counted. Countings were summed for each class then transformed into volume percentages of the total solid matter (soil matrix). Classes were determined from litter and soil components according to their origin (plant, animal, microbial, mineral) and the stage of decomposition or mineral weathering. This method, devised by Ponge (1984) and modified by Bernier \& Ponge (1994), allows determination of the percentage by volume of each class at a given depth. In the present study, 61 classes were identified (Table 2).

\section{Data analysis}

Data (percentages of occurrence of the 61 classes in the 40 samples) were subjected to correspondence analysis (CA), a multivariate method using the chi-square distance between individuals and between variables in a symmetrical manner (Greenacre, 1984; Ponge, 1993; Loranger et al., 2001). This method has also been called reciprocal averaging (Hill, 1973, 
1974). The different classes of humus components were the active variables, coded by their percentage of occurrence by volume, estimated by the corresponding number of points divided by the total number of points counted (Bernier \& Ponge, 1994). The nature of the corresponding horizon (OL, OF, A, S), the year (1999, 2002), the site (SI, SII, SIII) and the depth at which the samples were taken were treated as passive variables, i.e. they were projected on the factorial axes as if they had been involved in the analysis, without contributing to the factorial axes. They were coded as 1 or 0 . The absence of contribution of passive variables to factorial axes is the main difference between simple correspondence analysis (CA) and canonical correspondence analysis or CCA (Ter Braak, 1987). The absence of correction of the 'arch effect' or detrending by rescaling data is the main difference between the original method (CA) and detrended correspondence analysis or DCA (Hill \& Gauch, 1980). We preferred CA to CCA because the second method violates several of the original principles of CA established by Benzécri (1973), in particular that the model should follow the data and not the contrary. We preferred CA to DCA because the 'arch effect' appears when only one gradient is depicted by the data. In this case we prefer to project samples and variables on a single axis (Ponge et al., 1997; Loranger et al., 2001), avoiding the use of scatter graphs which show a distorted cloud of points.

In order to give the same weight to all variables (active and passive) they were transformed to mean 20 and unit variance by

$X=(x-m) / s+20$

where $x$ is the original value, $m$ is the mean of a given variable and $s$ is its standard deviation. The addition to each standardized variable of a constant 20 made all values positive, because correspondence analysis deals only with positive numbers, commonly counts (Greenacre, 1994). Following this transformation, factorial coordinates of variables can be interpreted directly in terms of their contribution to the factorial axes. The 
transformation used here gives to correspondence analysis most properties of the wellknown principal components analysis, while keeping the advantage of the simultaneous projection of variables and samples on the same factorial axes and the robustness due to the principle of distributional equivalence (Greenacre, 1984).

\section{Results}

Before pointing to the advantages of multivariate methods for the simultaneous analysis of all samples, we examine the information for the individual humus profiles.

\section{Examination of individual humus profiles}

Figures 1 to 3 represent the vertical distribution of main classes of humus components in the six profiles (Table 2). For simplifying the graphs, some classes were pooled. The graphic representation of humus components follows the method used commonly for results from pollen analyses and which Gillet \& Ponge (2002) have recently applied to the vertical distribution of humus components by replacing plant species by humus components and time by depth. As expected, the holm oak leaves were rapidly transformed into fragments and animal faeces, and these became rapidly enriched in mineral matter (Figure 1). The humus forms is typical of the mull group. The distribution of entire leaves changes with altitude, the OL horizon becoming thicker at higher elevation (compare Figure 1 with Figures 2 and 3). Accordingly, fragmented leaves occur deeper in the soil and the OF horizon becomes thicker when altitude increases. Roots are found in the OF horizon, but they are more abundant in the A horizon and still more in the S horizon. Mycorrhizae symbiotic with the ascomycete Cenococcum geophilum Fr. (jet black and shiny, with erect hair hyphae) follow the distribution of the whole root system of holm oak but their role increases with altitude. Rhizomorphs of Marasmius are present in OL and OF horizons, but disappear beneath. Organic-dominant animal faeces (small epigeic earthworms, insects and undetermined 
fauna) are present in the OL horizon, increase in volume in the OF horizon then progressively disappear in the upper part of the A horizon. Mineral-dominant animal faeces (enchytraeids and undetermined fauna) are almost absent from the OL horizon, but they are abundant (up to $36 \%$ of the soil matrix) in the OF and in the A horizon. They decrease abruptly in the $S$ horizon. Pure mineral matter increases steadily from OF to $A$ then to $S$ horizon, where it comprises the bulk of the soil matrix.

\section{Correspondence analysis}

The matrix analysed was composed of 40 columns (samples, see Table 1) and 61 rows (classes of humus components, see Table 2) with percentages of occurrence at the intercept, transformed as mentioned above. Axes 1 and 2 of correspondence analysis extracted $24 \%$ and $10 \%$ of the total variance, respectively. Classes of humus components (active variables) and of horizon names (passive variables) were projected in the plane of the first two factorial axes (Figure 4). The farther a variable was projected from the origin of the axes (barycentre) along a factorial axis, the more it contributed to this axis. We have not shown the projection of individual samples, because we prefer to deal with bulk variables such as depth levels, horizons, altitudes, years. This does not change anything to the analysis, but it simplifies the interpretation of the results. The cloud of humus components in

the plane formed by the the first two factorial axes shows the existence of three poles, corresponding to $\mathrm{OL}, \mathrm{OF}$ and $\mathrm{S}$ horizons, respectively. The $\mathrm{A}$ horizon is intermediate between OF and S, without any typical composition. The plane formed by the first two axes thus displays the vertical distribution of humus components. The simultaneous projection of depth indicators helps to visualize the vertical gradient. The OL horizon is most often restricted to the topmost centimetre, whereas the OF horizon is expressed mostly between 2 and $4 \mathrm{~cm}$ depth, the $A$ horizon between 5 and $6 \mathrm{~cm}$ and the $S$ horizon underneath. Notice that indicators of depth or horizon names help to reveal mean trends, without taking into account the variation which may occur from a humus profile to another. 
A wide variety of litter components (24 among 61 ) are present in the OL horizon, expressing the variety of plant organs from several species which fall on the ground. Brown as well as bleached entire and nibbled oak leaves can be recognized (classes 1, 2, 3, 4), as well as herb leaves (8), Cistus leaves (9), Juniperus oxycedrus needles and galbuli $(10,11)$, and other organs such as acorns (12), buds (15), flowers (16), twigs (17), petioles (19), wood (22). Lichens (23), living and dead mosses $(24,25)$, rhizomorphs of Marasmius quercophilus $(39,40)$, entire and fragmented arthropod cuticles $(60,61)$ are also components of this superficial horizon, which reflects the composition of litter fall and the first stages of its degradation (nibbling by fauna, bleaching by white rot).

The OF horizon consists mainly of brown and bleached oak leaf fragments (classes 5 , 6), bleached leaves skeletonized by fauna (7). Organic-dominant faeces (44, 46, 48), hemorganic enchytraeid faeces (43), mineral-dominant faecal masses (49), complex assemblages of holomineral faeces and mycelia, with (51) or without roots (50), and mycelial masses (42) constitute other typical components of this horizon. Thus this horizon is the main centre of microbial and faunal activities in the litter, and mineral matter is mixed with the litter there through the deposition of mineral or hemorganic faeces.

Although the composition of the A horizon is not as typical as that of other horizons, some components are more abundant in this horizon than in the others. This is so for fine roots (27), mycorrhizae $(36,41)$, unidentified plant fragments (26), unidentified mineraldominant faeces (47), but coarse sand (56) and gravels (59) are also present. The development of the feeder root system of oak is prominent in this hemorganic horizon.

The S horizon, in addition to its richness in fine sand (57) and weathered rock (58), is the centre for living and dead lignified roots $(29,30,31,32,33)$, decaying unlignified fine roots and mycorrhizae $(28,34,37)$, as well as roots and plant fragments embedded in 
mineral matter $(35,55)$. Sclerotia of $C$. geophilum $(38)$ are also present. Typically this horizon shows the anchorage of the root system of oak in the weathering parent rock. Note that in this horizon large roots (33) as well as fine roots (34) are often attacked by the mycorrhizal fungus $C$. geophilum, which gives them a jet black colour.

The projection of passive variables corresponding to sites (SI, SII, SIII) revealed the effects of altitude on the composition of humus profiles, although these effects are not as pronounced as depth (as shown by their distance to the origin, shorter than that of horizon names). In SI, situated on the positive side of axis 2, humus profiles show a more rapid transition from the OL horizon to the S horizon than in SII and SIII, projected on the negative side of Axis 2 (see also Figures 1, 2, 3). This phenomenon is better visualized by the projection of depth indicators when the three sites are distinguished (Figure 5). The SI run does not exhibit pronounced trends towards the negative side of Axis 2, in contrast to SII and more especially SIII. Moreover, the OL horizon is thicker at SIII than in the lower two sites, since in the upper site the OF horizon is not reached before $3-4 \mathrm{~cm}$ depth. The $S$ horizon is reached as soon as $4-5 \mathrm{~cm}$ at $\mathrm{SI}$, but not before $6-7 \mathrm{~cm}$ at SII, and $7-8 \mathrm{~cm}$ at SIII.

The projection of year indicators in the plane of the first two axes (Figure 4) reveals changes according to year, in particular changes in the respective development of horizons could be suspected. The projection of depth indicators separated by years may throw light on this pattern (Figure 6). In 1999, at 2-3 cm depth the litter exhibits a composition intermediate between that of an OL and that of an OF horizon, while in 2002 it has typically the composition of an OF horizon. This can be seen on Figures 1, 2, 3, by comparing the ultimate depths at which entire and nibbled leaves (which comprise the bulk of the OL horizon) are still present in 1999 (left side) and 2002 (right side). This means that the OL horizon was thicker in 1999 than in 2002, although this was not perceived to the naked eye in the field (see horizon thicknesses at the bottom of Figures 1 to 3 , see also Table 1). Another trend depending on the year is the composition of the S horizon. In 2002 the composition of 
this horizon is clearly different from that of the A horizon, while differences between the two horizons are not so pronounced in 1999 (Figure 6). Examination of original data reveals that decaying roots $(28,30,32,34)$, classified as typical of the $S$ horizon by the analysis, were more abundant in 2002 than in 1999, reaching 18.4\% of the total matrix in 2002 at SIII (compared to $8.6 \%$ in 1999), $16.6 \%$ in 2002 at SIl (compared to $9.9 \%$ in 1999). The same phenomenon was not observed at lower altitude (13.3\% in 2002, 13.1\% in 1999 at SI).

\section{Discussion and conclusion}

The humus profiles we examined under $Q$. rotundifolia contained much activity by fungi and fauna, despite the resistence to decay of the dead oak oak leaves. Dysmull, characterized by the presence of a thick OF horizon and an A horizon with a crumby structure (Brêthes et al., 1995), was constant, in both years and at all three elevations. Fauna evidently had nibbled and skeletonized the holm oak leaves, even in the OL horizon, and had deposited of faecal pellets in the underlying OF horizon. Faeces from small earthworms (organic-dominant), enchytraeids (hemorganic) and insect larvae (holorganic) occurred in this horizon. Despite its crumby structure, the A horizon was imperfectly expressed. Rather, it was transitional between the OF horizon, enriched in mineral matter through the deposition of mineral faeces (mostly enchytraeids), and the S horizon, which was the source of mineral matter for these tiny oligochaetes. By the importance of enchytraeid activity, the observed Dysmull shares several properties with moder, except that in moder holorganic faeces accumulate, forming a dark, organic-dominant $\mathrm{OH}$ horizon (Ponge, 1999). Under the Mediterranean climate, fauna are active deeper than under moister and colder climate, which favours the mixing of organic matter with mineral matter (Peltier et al., 2001). Causes can be found in (i) dryness of the litter during the summer, which makes it inaccessible to drought-intolerant animals, such as enchytraeids (Babel, 1977; Abrahamsen, 1972), and (ii) the deep development of roots, which makes them better protected from desiccation (Salisbury \& Ross, 1985). Roots are 
important food for animals living in the soil (Baylis et al., 1986; Gunn \& Cherrett, 1993). In the humus profiles studied they were found mainly in the $S$ horizon.

The influence of altitude appears mainly through an increase in the thickness of OF and A horizons (seen mainly in Site SII at $1700 \mathrm{~m}$ ) and in the thickness of the OL horizon (seen mainly in Site SIII, at 1900 m). Lower temperature is the main cause of the decrease in soil biological activity at higher altitude (van Cleve \& Sprague, 1971; Djellali et al., 1985). It seems that the increase in thickness of OF and A horizons (where most fauna are active) is due mainly to less microbial activity (slower mineralization of organic matter once incorporated into animal faeces), whilst the increase in thickness of the OL horizon is likely to be due to less faunal activity (slower fragmentation of litter, delaying the passage to the OF horizon). Note, however, that the humus form did not change with altitude, probably because the threshold of resilience of the mull type was not reached within the altitudinal range studied (Belotti \& Babel, 1993).

We did not measure litter fall for this study, and so we can only speculate about the effects of variations in litter input between the two years 1999 and 2002. The fact that more roots were dead in 2002, whilst litter was thinner, was possibly due to a lack of protection of the root system from desiccation during the warm season in years with a poor litter fall. If this is true, this may have consequences for the composition and the vertical distribution of animal and microbial communities in the soil, since it implies an alternation in the disposal of two important food sources: roots (in years with little litter input) and foliage (in years when there was much).

Correspondence analysis proved useful for the simultaneous analysis of several humus profiles, especially in the absence of replication, i.e. when dealing with heterogeneous environments. 


\section{References}

Abrahamsen, G. 1972. Ecological study of Enchytraeidae (Oligochaeta) in Norwegian coniferous forest soils. Pedobiologia, 12, 26-82.

Achhal, A., Akabli, O., Barbero, M., Benabid, A., M'hirit, A., Peyre, C., Quezel, P. \& RivasMartinez, S. 1980. A propos de la valeur bioclimatique et dynamique de quelques essences forestières au Maroc. Ecologia Mediterranea, 5, 211-248.

Babel, U. 1977. Influence of high densities of fine roots of Norway spruce on processes in humus covers. Ecological Bulletins, 25, 584-586.

Barbero, M. \& Loisel, R. 1980. Le chêne vert en région méditerranéenne. Revue Forestière Française, 32, 531- 543.

Baylis, J.P., Cherrett, J.M. \& Ford, J.B. 1986. A survey of the invertebrates feeding on living clover roots (Trifolium repens L.) using ${ }^{32} \mathrm{P}$ as a radiotracer. Pedobiologia, 29, 201208

Beauchamp, J. \& Biron, P. 1982. Reconstitution d'un milieu de sédimentation dans les molasses rouges Triasiques du Haut Atlas. Bulletin de la Faculté des Sciences de Marrakech, 1, 47-57.

Belotti, E. \& Babel, U. 1993. Variability in space and time and redundancy as stabilizing principles of forest humus profiles. European Journal of Soil Biology, 29, 17-27.

Benzécri, J.P. 1973. L'analyse des données. II. L'analyse des correspondances. Dunod, Paris. 
Bernier, N. \& Ponge, J.F. 1994. Humus form dynamics during the sylvogenetic cycle in a mountain spruce forest. Soil Biology and Biochemistry, 26, 183-220.

Brêthes, A., Brun, J.J., Jabiol, B., Ponge, J.F. \& Toutain, F. 1995. Classification of forest humus forms: a French proposal. Annales des Sciences Forestières, 52, 535-546.

Djellali, N., Billès, G., Bounaga, N. \& Lossaint, P. 1985. Étude de l'activité biologique des sols de la steppe à alfa d'Algérie. Minéralisation du carbone et de l'azote. Acta Oecologica, Oecologia Plantarum, 6, 289-307.

Gillet, S. \& Ponge, J.F. 2002. Humus forms and metal pollution in soil. European Journal of Soil Science, 53, 529-539.

Greenacre, M.J. 1984. Theory and Applications of Correspondence Analysis. Academic Press, London.

Gunn, A. \& Cherrett, J.M. 1993. The exploitation of food resources by soil meso- and macro invertebrates. Pedobiologia, 37, 303-320.

Hill, M.O. 1973. Reciprocal averaging: an eigenvector method of ordination. Journal of Ecology, 61, 237-249.

Hill, M.O. 1974. Correspondence analysis: a neglected multivariate method. Applied Statistics, 23, 340-354.

Hill, M.O. \& Gauch, H.G. 1980. Detrended correspondence analysis: an improved ordination technique. Vegetatio, 42, 47-58. 
Lavelle, P. 1987. Interactions, hiérarchies et régulations dans le sol: à la recherche d'une nouvelle approche conceptuelle. Revue d'Écologie et de Biologie du Sol, 24, 219-229.

Lavelle, P. 2000. Ecological challenges for soil science. Soil Science, 165, 73-86.

Loranger, G., Bandyopadhyaya, I., Razaka, B. \& Ponge, J.F. 2001. Does soil acidity explain altitudinal sequences in collembolan communities. Soil Biology and Biochemistry, 33, 381-393.

Peltier, A., Ponge, J.F., Jordana, R. \& Ariño, A. 2001. Humus forms in mediterranean scrublands with aleppo pine. Soil Science Society of America Journal, 65, 884-896.

Poli, E., Leonardi, S. \& Bella, R. 1974. Produzione di littiera nella lecceta del M. Minardo (Etna) nel periodo Settembre 1970-Giugnio 1974. Archivio Botanico e Biogeografico Italiano, 50, 86-106.

Ponge, J.F. 1984. Étude écologique d'un humus forestier par l'observation d'un petit volume, premiers résultats. I. La couche L1 d'un moder sous pin sylvestre. Revue d'Écologie et de Biologie du Sol, 21, 161-187.

Ponge, J.F. 1993. Biocenoses of Collembola in Atlantic temperate grass-woodland ecosystems. Pedobiologia, 37, 223-244.

Ponge, J.F. 1999. Horizons and humus forms in beech forests of the Belgian Ardennes. Soil Science Society of America Journal, 63, 1888-1901. 
Ponge, J.F., Arpin, P., Sondag, F. \& Delecour, F. 1997. Soil fauna and site assessment in beech stands of the Belgian Ardennes. Canadian Journal of Forest Research, 27, 2053-2064.

Rapp, M. 1971. Cycle de la matière organique et des éléments minéraux dans quelques écosystèmes méditerranéens. In: Cycle de la Matière Organique et des Éléments Minéraux dans quelques Écosystèmes Méditerranéens. Dynamique Saisonnière de deux Sols en Climat Tempéré, pp. 28-184. CNRS, Paris.

Sadaka-Laulan, N. \& Ponge, J.F. 2000a. Comparative leaf decomposition within the holm oak complex. European Journal of Soil Biology, 36, 91-95.

Sadaka-Laulan, N. \& Ponge, J.F. 2000b. Influence of holm oak decomposition stage on the biology of Onychiurus sinensis Stach (Collembola: Onychiuridae). European Journal of Soil Biology, 36, 97-105.

Salisbury, F.B. \& Ross, C.W. 1985. Plant Physiology, $3^{\text {rd }}$ edition. Wadsworth Publishing Company, Belmont, California.

Ter Braak, C.J.F. 1987. The analysis of vegetation-environment relationships by canonical correspondence analysis. Vegetatio, 69, 69-77.

van Cleve, K. \& Sprague, D. 1971. Respiration rates in the forest floor of birch and aspen stands in Interior Alaska. Arctic and Alpine Research, 3, 17-26. 


\section{Legends of figures}

Figure 1 Vertical distribution of the main components of the soil matrix (class numbers indicated in Table 2) at Site SI (1500 m). Depth as abscissa. Percentage of the total matrix volume as ordinate (arbitrarily mirrorred on the negative axis for clarity).

Figure 2 Vertical distribution of the main components of the soil matrix (class numbers indicated in Table 2) at Site SII (1700 m). Depth as abscissa. Percentage of the total matrix volume as ordinate (arbitrarily mirrorred on the negative axis for clarity).

Figure 3 Vertical distribution of the main components of the soil matrix (class numbers indicated in Table 2) at Site SIII (1900 m). Depth as abscissa. Percentage of the total matrix volume as ordinate (arbitrarily mirrorred on the negative axis for clarity).

Figure 4 Correspondence analysis. Projection of humus components (categories, codes in Table 2), sites, years and depth indicators in the plane of the first two factorial axes.

Figure 5 Correspondence analysis. Projection of depth indicators (for each site) in the plane of the first two factorial axes. Successive depths are linked by continuous or broken lines.

Figure 6 Correspondence analysis. Projection of depth indicators (for each year) in the plane of the first two factorial axes. Successive depths are linked by continuous or broken lines. 
Table 1 Layers (with their thickness in $\mathrm{cm}$ ) sampled in the three study sites. A dash means that the layer was not present in the profile studied

\begin{tabular}{|c|c|c|c|c|c|c|}
\hline & SI (1999) & SII (1999) & SIII (1999) & SI (2002) & SII (2002) & SIII (2002) \\
\hline OL1 & 0.5 & 0.5 & 1.0 & 0.5 & 1.0 & 1.0 \\
\hline OL2 & - & 0.5 & 1.5 & - & - & 1.5 \\
\hline OF1 & 1.5 & 2.5 & 0.5 & 1.0 & 1.5 & 2.0 \\
\hline OF2 & - & 1.5 & 2.0 & 1.5 & 1.5 & - \\
\hline A1 & 2.0 & 1.0 & 1.5 & 2.5 & 2.0 & 1.5 \\
\hline $\mathrm{A} 2$ & - & 1.5 & 1.0 & - & 2.0 & 1.5 \\
\hline S1 & 2.0 & 2.5 & 2.0 & 2.0 & 1.5 & 1.5 \\
\hline $\mathrm{S2}$ & 2.5 & - & 1.5 & 2.5 & 2.0 & 2.0 \\
\hline $\begin{array}{l}\text { Total } \\
\text { thickness }\end{array}$ & 8.5 & 10 & 11 & 10 & 11.5 & 11 \\
\hline
\end{tabular}


Table 2 The classes of humus components, coded by numbers

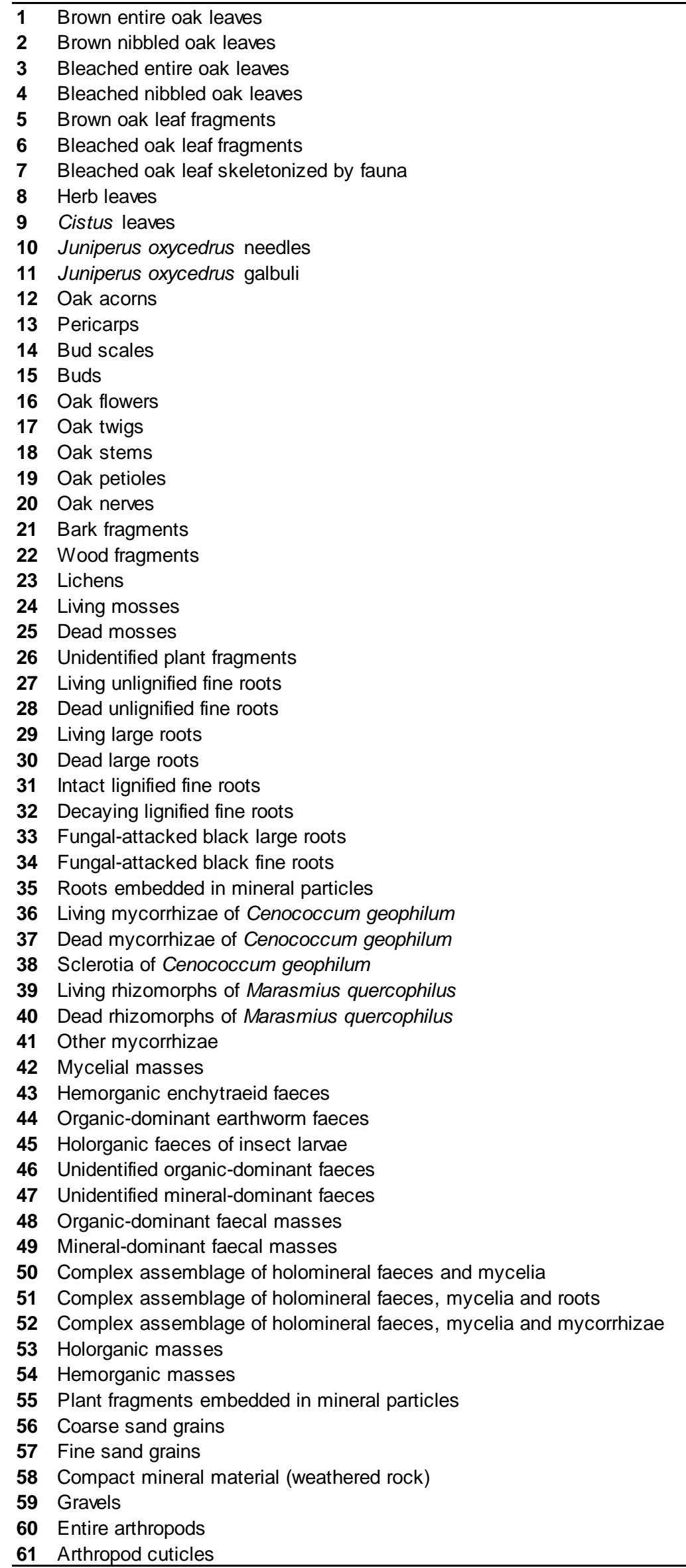



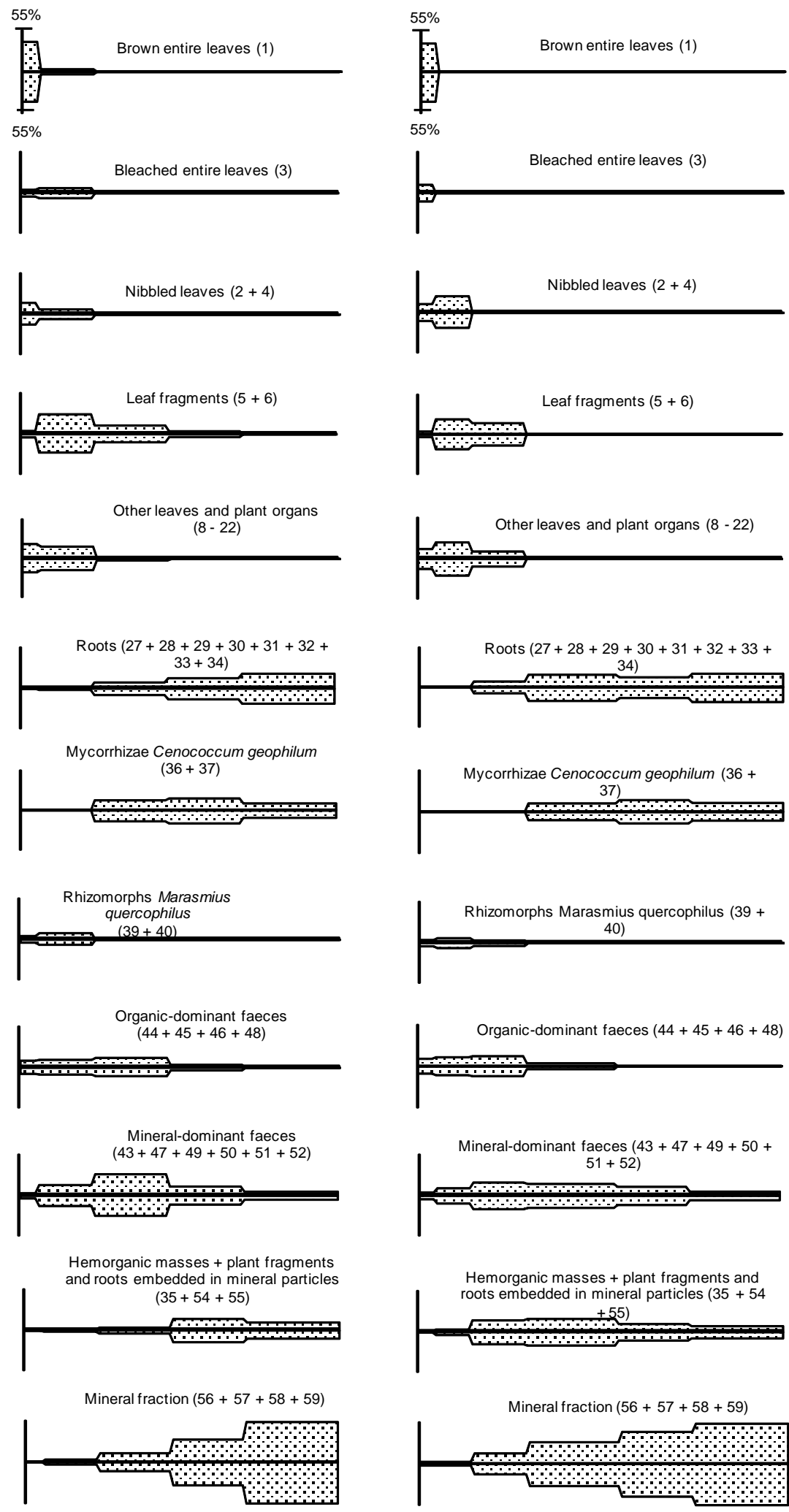

Depth / cm
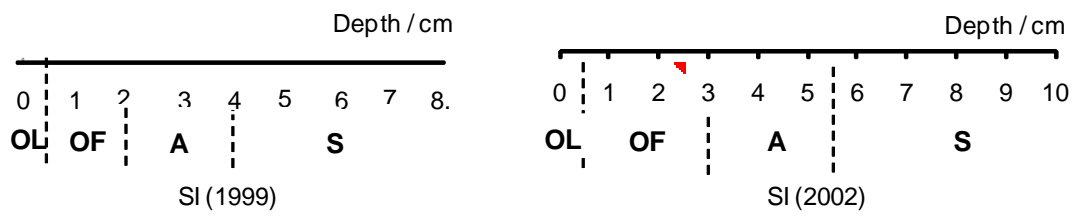

Fig. 1 

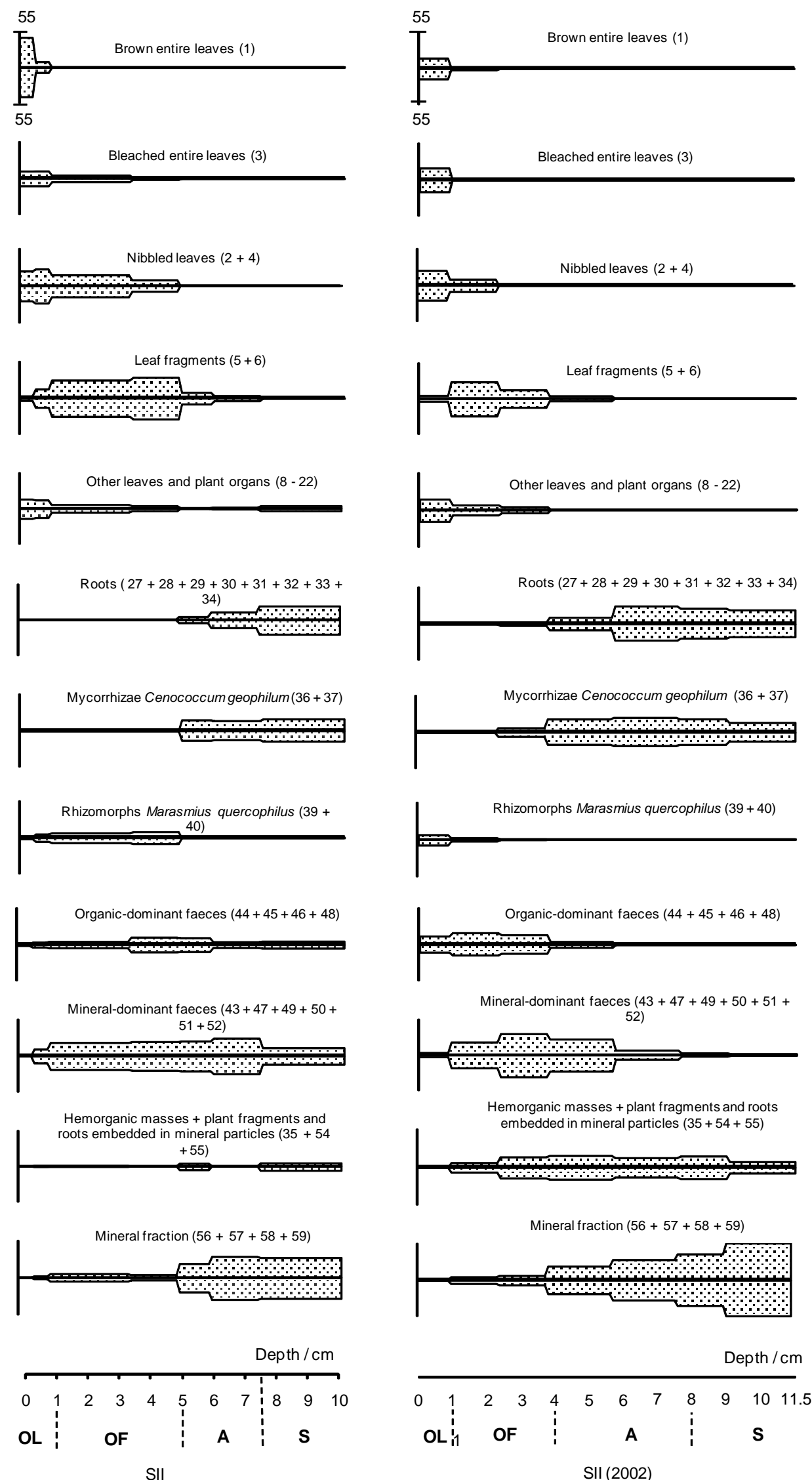

SII (2002)

Fig. 2 


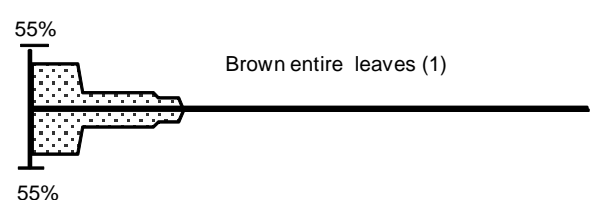

Bleached entire leaves (3)
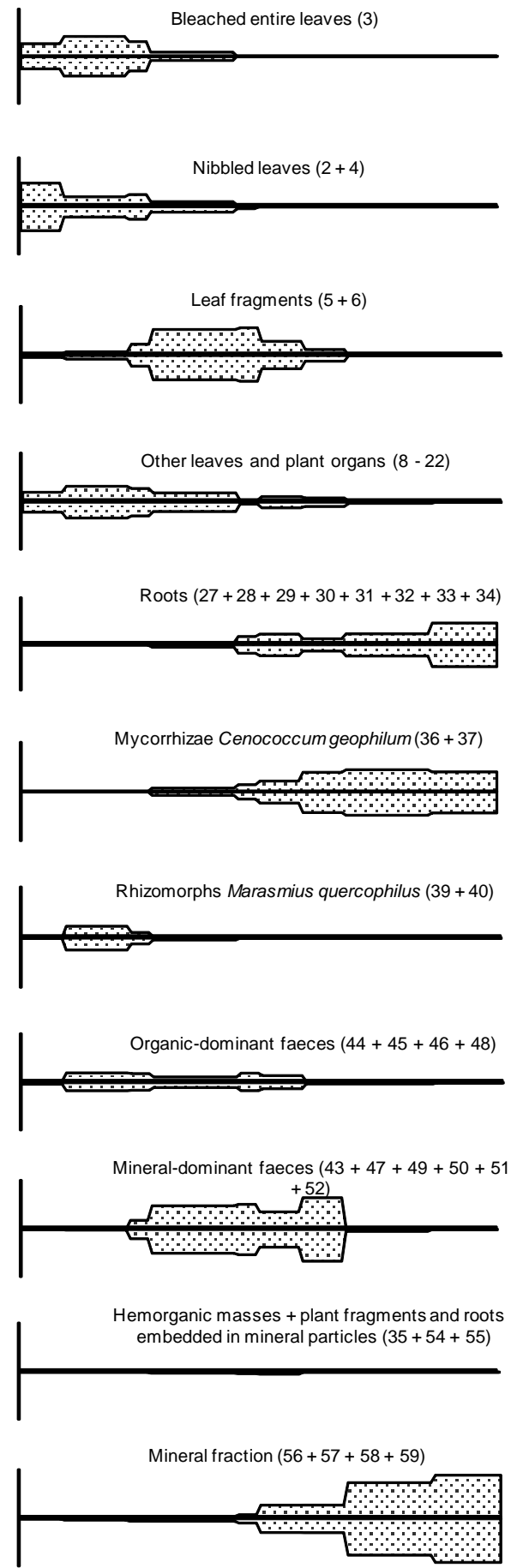

Depth / cm

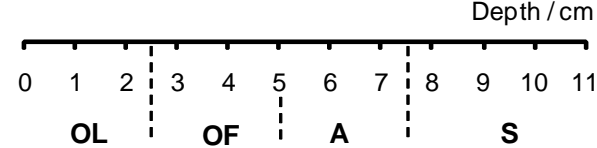

SIII (1999)
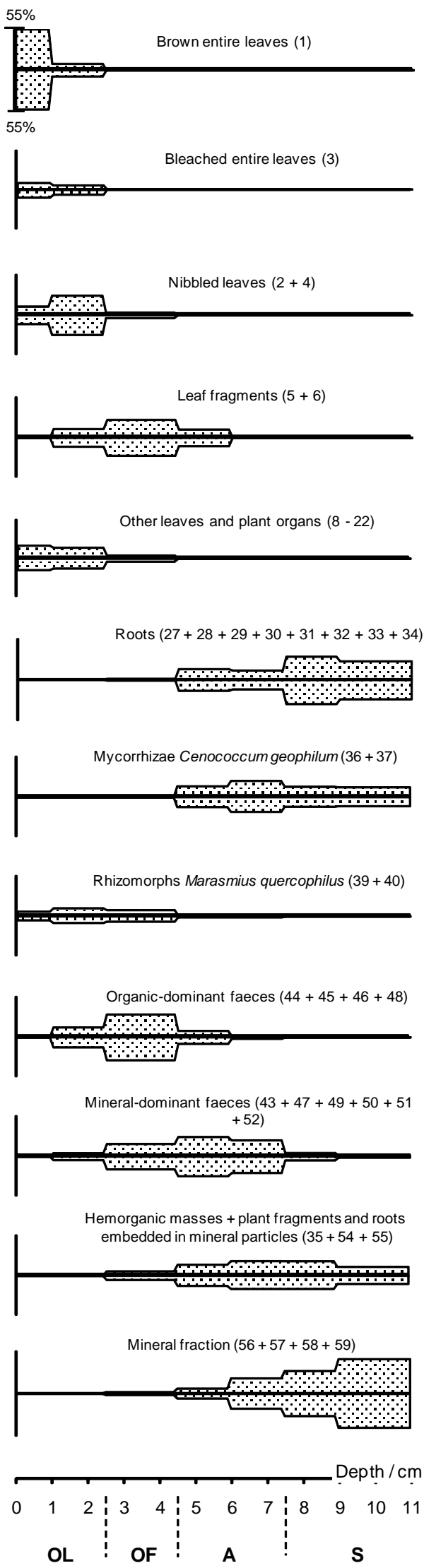

SIII (2002)

Fig. 3 


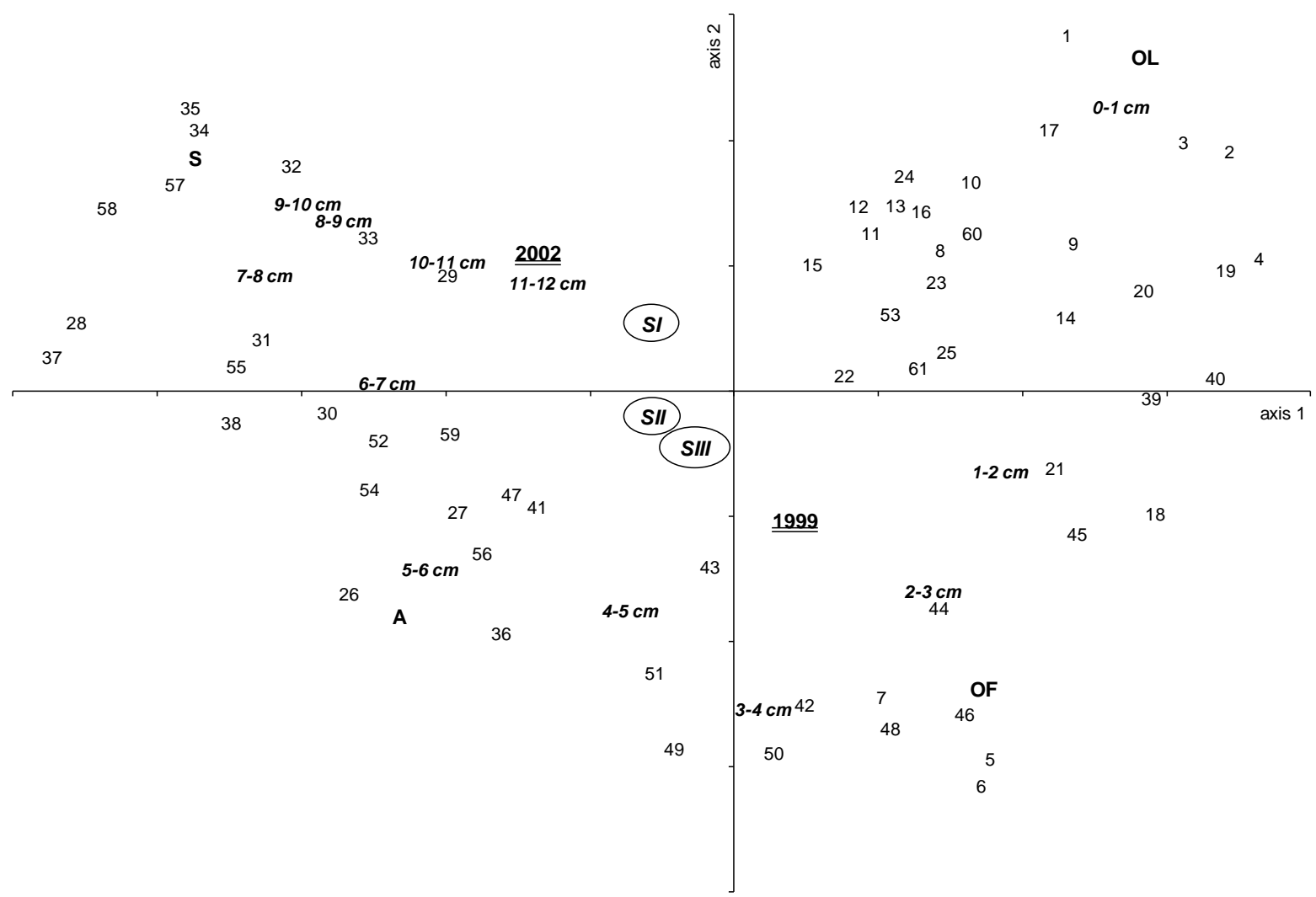

Fig. 4 


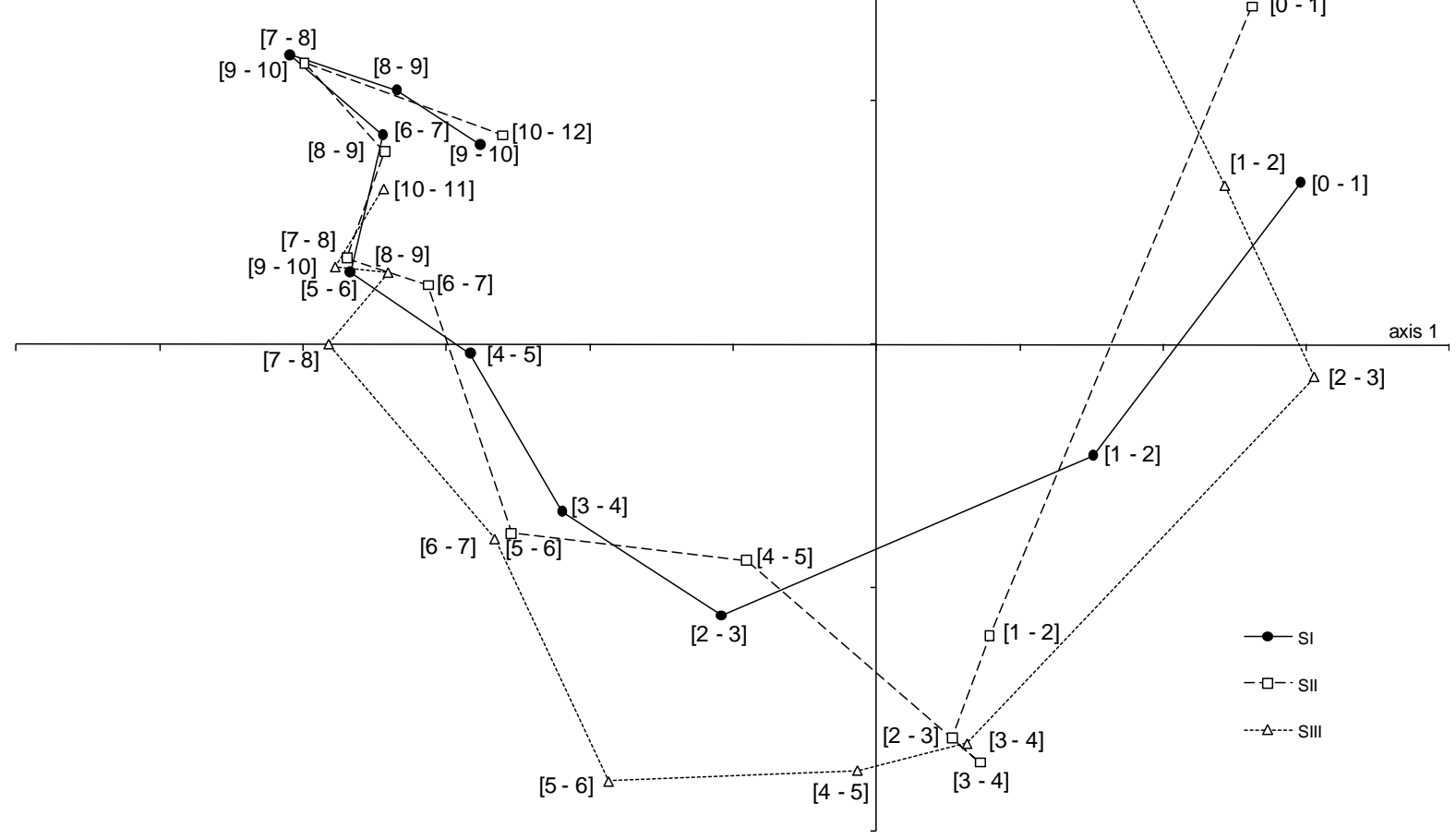

Fig. 5 


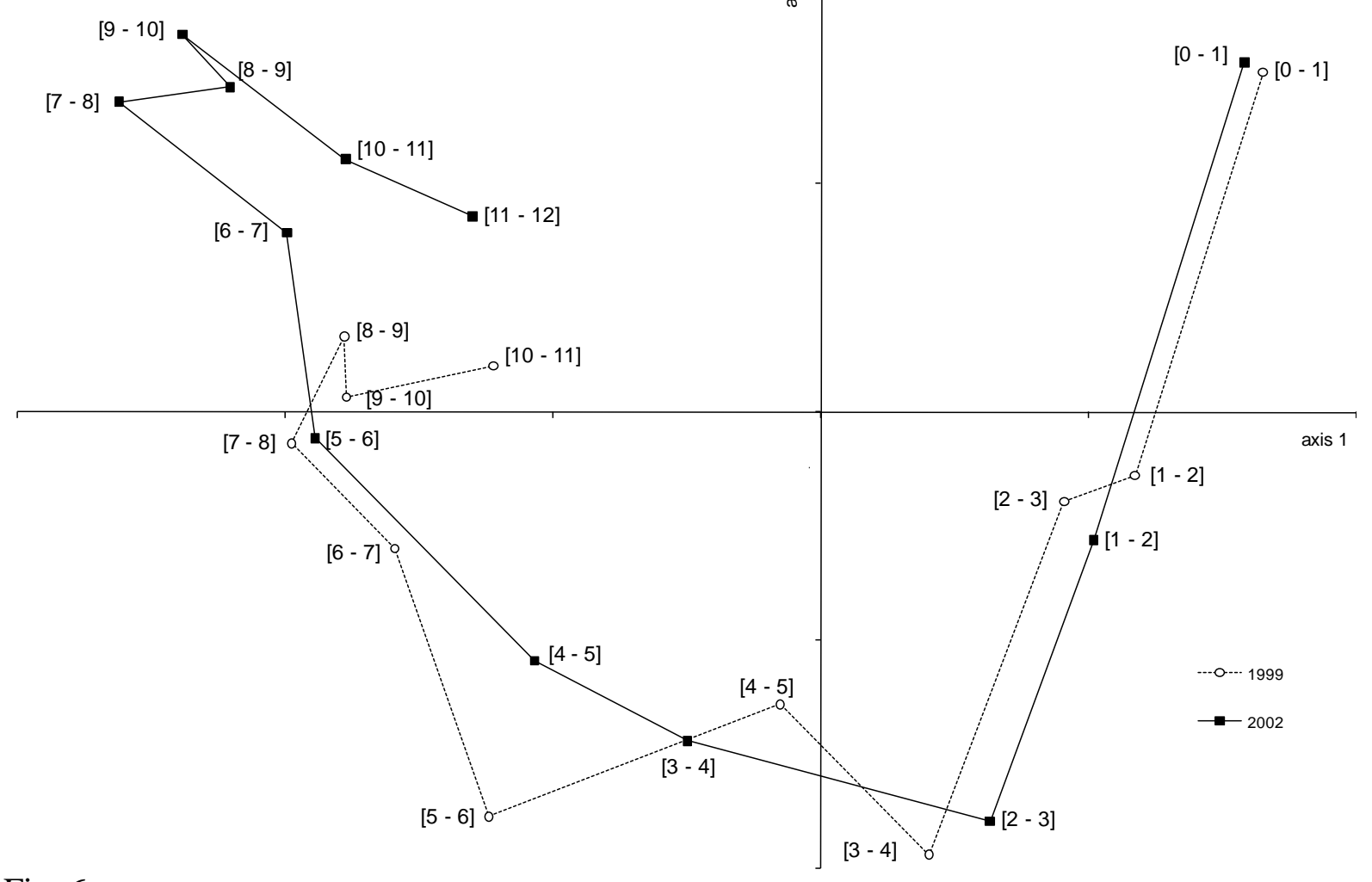

Fig. 6 